УДК 633.854.79.003.13

(C) 2012

Білітюк А. П., кандидат сільськогосподарських наук

Волинський інститут агропромислового виробництва

Гарбар Л. А., кандидат сільськогосподарських наук, Циганчук С. М., матістр

Національний університет біоресурсів і природокористування України

\title{
ВПЛИВ ЕЛЕМЕНТІВ ТЕХНОЛОГІЇ ВИРОЩУВАННЯ НА ПРОДУКТИВНІСТЬ ПШЕНИЦІ ОЗИМОЇ В УМОВАХ ЗАХІДНОГО ПОЛІССЯ УКРАЇНИ
}

\section{Рецензент - кандидат сільськогосподарських наук В. М. Рожко}

\begin{abstract}
Вивчено вплив строків сівби та норм висіву на формування продуктивності сортів пшениці озимої в умовах Західного Полісся Украӥни. Результати досліджень показали, щуо посіви пшениці озимоі на дерново-підзолистих на фоні $N_{60} P_{60} K_{60}$ максимальну врожайність формували за сівби сорту Золотоколоса 30.09 за норми висіву 5 млн. схожих насінин на га - 6,48 m/2а, а сорту Смуглянка - за сівби 10.10 за аналогічної норми висіву - 6,32 m/2a. Найвищі показники якості зерна пшениџі (вміст білка та клейковини) було отримано за сівби сорту Смуглянка - 20.10, Золотоколоса - 10.10.
\end{abstract}

Ключові слова: пшениця озима, сорти, технологія вирощування, потенціал, норми висіву, строки сівби, продуктивність, якість.

Постановка проблеми. Пшениця озима широко вирощується в Україні із застосуванням сучасної інтенсивної технології, що полягає в оптимізації умов вирощування пшениці на всіх етапах росту й розвитку рослин і передбачає розміщення культур після кращих попередників, використання інтенсивних сортів і застосування добрив на заплановану врожайність й інтегрованої системи захисту рослин від бур'янів, хвороб та шкідників. Важливою умовою підвищення врожайності пшениці є використання для сівби високоякісного насіння кращих районованих сортів, пристосованих до місцевих умов вирощування.

Iз метою управління процесами формування урожаю необхідно мати чітке уявлення про взаємодію всіх факторів, які істотно впливають на урожайність. Основним фактором підвищення продуктивності пшениці озимої $є$ поліпшення структури посіву, яка зумовлюється густотою стеблостою, що насамперед залежить від норми висіву, строків сівби, польової схожості насіння та виживання рослин [7].

Аналіз останніх досліджень і публікацій, у яких започатковано розв'язання проблеми. Багаточисельні дослідження свідчать, що тільки за оптимальних строків сівби рослини пшениці озимої здатні повністю використовувати всі необхідні чинники для свого росту та розвитку i забезпечувати найвищий урожай культури. Як за ранніх, так і за пізніх строків сівби продуктивність рослин знижується $[2,4]$.

Строки сівби суттєво впливають на час появи $\mathrm{i}$ повноту сходів, наступний ріст і розвиток рослин й, відповідно, величину врожаю. Від строків сівби залежить проходження усіх фаз розвитку рослин і стійкість їх до ураження хворобами та шкідниками, а також до несприятливих умов перезимівлі.

Найвищий урожай пшениці озимої отримують за формування до часу припинення осінньої вегетації двох-чотирьох пагонів. Для дотримання цієї умови необхідно проводити сівбу, щоб за осінній період вегетації (від сівби до припинення вегетації) сума середньодобових температур дорівнювала 550-580 등 що становить 46-60 днів.

У питанні про ступінь морозостійкості пшениці озимої залежно від строків сівби єдиної думки немає. Одні дослідники стверджують, що пшениця озима ранніх строків сівби стає більш морозостійкою, ніж пізніх, інші вважають кращою у формуванні цієї властивості сівбу в оптимальні строки. Нарешті, треті дотримуються думки, що найбільш морозостійкими є рослини пшениці озимої пізніх строків сівби.

За ранніх строків сівби рослини пшениці озимої до замерзання грунту проходять стадію яровизації, а в окремих випадках можуть навіть виходити в трубку, що знижує їх здатність до загартовування.

Відомо, наскільки суттєве значення у формуванні морозостійкості надається температурному фактору. Якщо рослини вирощують спочатку при підвищених температурах, а пізніше - в умовах понижених, то їх морозостійкість підвищується. Тривале вирощування при високих 
температурах призводить до зниження морозостійкості, а при понижених - до їі підвищення. Особливо помітно підвищується морозостійкість рослин, якщо температура повітря становить близько $0{ }^{\circ} \mathrm{C}$ : затримується ріст рослин, і в них відбувається нагромадження органічних речовин та зменшується витрата їх у процесі дихання. При пониженій середньодобовій температурі рослини інтенсивніше кущаться.

Як вказують М. Ф. Бомб, В. В. Лихочвор [1], за пізніх строків сівби вузол кущіння утворюється на більшій глибині, ніж за ранніх. За ранніх строків сівби глибина залягання вузла кущіння не перевищує 1,0-1,5 см, тоді як у рослин пізніх строків вона зростає до 3,5-4,0 см.

Інтенсивність кущіння залежить від багатьох факторів. Так, у дослідах В. В. Лихочвора [5] коефіцієнт кущення зростає за ранніх строків сівби $(1,6-3,1)$ і зменшується за пізніх $(1,1-2,1)$. Збільшення кущистості сприяє надмірній витраті вологи та поживних речовин, оскільки бокові пагони, зменшуючи забезпеченість головного стебла водою й елементами живлення, не компенсують його втрати урожаєм. До того ж головні пагони дають краще за якістю зерно.

Окремі вчені [3] відмічають, що оптимальний розвиток пшениці озимої в осінній період - важливий фактор нормальної перезимівлі й високого стабільного урожаю. В зимовий період як перерослі, так і слаборозвинені рослини зріджуються.

Рослини пізнього строку сівби з осені не забезпечуються світловою енергією, необхідною для переходу до диференціації конуса наростання. Тому вони навесні повинні ще продовжувати рости, витрачати пластичні речовини, після чого лише приступають до формування колоса, коли створюються умови, що не відповідають вимогам рослин на початкових етапах росту і розвитку - температура стає високою, грунт сухішим, а освітлення інтенсивнішим.

В усіх зонах України найвищі врожаї зерна одержують за оптимальних строків сівби, що встановлюються 3 урахуванням грунтовокліматичних умов, особливостей сорту, агротехніки і погоди в передпосівний період [4].

Намагання вчених дати теоретичне обгрунтування строків сівби стосовно місцевих кліматичних умов зазнавали невдачі. Чимала заслуга у вирішенні цього питання належить професору A. I. Носатовському [6], який уперше до визначення кращого строку сівби пшениці озимої підійшов 3 урахуванням біології рослини пшениці, вимог до умов вирощування, стійкості до хвороб, шкідників і несприятливих умов перезимів- лі залежно від розвитку рослин.

Численними дослідниками i виробничою практикою встановлено, що для кожного сорту існує оптимальний строк сівби, за якого найповніше задовольняються біологічні потреби сорту при вирощуванні.

Строки сівби істотно впливають і на якість зерна пшениці озимої. Сівба в оптимальні (для конкретних умов) строки забезпечує отримання високих врожаїв і сприяє формуванню відносно добрих фізичних і технологічних якостей зерна (підвищується маса 1000 зерен, натура і вміст сирої клейковини). Сівба в ранні строки призводить до зниження білковості та погіршення хлібопекарських якостей зерна. За більш пізніх строків сівби вміст у зерні клейковини буває вищим, аніж за оптимальних.

Отже, огляд літературних джерел свідчить про те, що строки сівби $є$ важливим фактором продуктивності пшениці озимої і не можуть бути постійними в різні роки: вони диференціюються залежно від інших агротехнічних заходів, передусім таких як сортові особливості, попередники, обробіток грунту, тип грунту.

Метою наших досліджень було вивчення впливу строків сівби та норм висіву на формування продуктивності пшениці озимої за конкретних умов вирощування.

Умови та методика проведення досліджень. Дослід із вивчення строків сівби та норм висіву пшениці озимої проводився у III селекційній сівозміні на полях Волинського інституту АПВ c. Рокині Луцького району Волинської області. Рельєф - рівнинний. Грунт дослідної ділянки дерново-підзолистий. Вміст в орному шарі грунту (0-20): фосфору - 15,3, калію - 18,9, азоту 8,61 мг на 1 кг абсолютно сухого грунту, $\mathrm{pH}-$ 5,97 .

Попередник - горох. Підготовку грунту проводили за загальноприйнятою технологією, рекомендованою для озимих зернових в умовах Західного Полісся. Мінеральні добрива $\left(\mathrm{P}_{60} \mathrm{~K}_{60}\right)$ вносили в передпосівний обробіток, азотні $\left(\mathrm{N}_{60}\right)$ - вроздріб навесні. Перше підживлення азотом проводили в першій декаді квітня за весняного відновлення вегетації з розрахунку 30 кг діючої речовини на гектар посіву, друге $\left(\mathrm{N}_{30}\right)$ підживлення - на IV етапі органогенезу.

Сівбу проводили сівалкою СН-16 згідно зі схемою досліду. Дослід трьохфакторний: фактор А - сорти (Золотоколоса, Смуглянка); фактор В - строки сівби: 1) 20.09 (контроль), 2) 30.09; 3) 10.10 ; 4) 20.10; фактор С - норми висіву: 1) 4 млн схожих насінин на га; 2) 5 млн схожих 
насінин на га; 3) 6 млн схожих насінин на га. Повторюваність досліду - чотирьохразова. Площа посівної ділянки - $50 \mathrm{~m}^{2}$, облікової - $40 \mathrm{~m}^{2}$.

Результати досліджень. Правильно вибрані оптимальний строк і норми висіву нових сортів пшениці озимої відіграють важливу роль у технології їх вирощування й вимагають диференційованого підходу залежно від біологічних особливостей сорту та умов вирощування.

Основним показником реалізації біологічного потенціалу культури, залежно від досліджуваних факторів, є врожайність. Динаміка змін рівнів урожайності під впливом вивчених факторів наведена в таблиці.

Аналізуючи отримані результати, варто зауважити: більш сприятливим для розвитку рослин пшениці озимої та формування ії продуктивності виявився 2010/2011 вегетаційний рік, що дало змогу отримати прирости врожаю у досліджуваних сортів від 0,41 до 1,03 т/га залежно від норм висіву та строків сівби в порівнянні 3 минулим вегетаційним періодом культури (див. табл.).

Якщо ж аналізувати прирости врожаю віднос- но рекомендованих строків сівби даної культури (20.09) в досліджуваному регіоні, то вищі показники було отримано у сорту Смуглянка за сівби 10.10 , які становили $0,72-0,85$ т/га; дещо поступалися показники варіанту 3 терміном сівби $30.09(0,72-0,74$ т/га), тоді як у сорту Золотоколоса показники, відповідно, варіювали в межах 0,42-0,52 т/га, та 0,61-0,72 т/га.

Результати досліджень показали, що на формування продуктивності посівів пшениці озимої мали вплив як строки сівби, так і норми висіву. Проте в ході досліджень суттєвого приросту врожаю під впливом різних норм висіву не було виявлено. Залежно від строків сівби змінювались і оптимальні норми висіву, - при цьому чіткої закономірності в ході досліджень не було встановлено.

Сорт із генетично обумовленими показниками якості $\epsilon$ основою виробництва доброякісного зерна. Проте йому необхідно створити умови, за яких найбільш сповна реалізується потенційна врожайність та якість зерна. Важливими елементами технології вирощування, ефективно діючих на якість зерна, $є$ строки сівби, система удобрення й інші.

Вплив строків сівби і норм висіву на урожайність та якість зерна пшениці озимої

\begin{tabular}{|c|c|c|c|c|c|c|c|c|}
\hline \multirow{2}{*}{$\begin{array}{c}\text { № } \\
\text { вар. }\end{array}$} & \multirow{2}{*}{$\begin{array}{c}\text { Сорт, } \\
\text { строки сівби }\end{array}$} & \multirow{2}{*}{$\begin{array}{l}\text { Норми } \\
\text { висіву }\end{array}$} & \multicolumn{2}{|c|}{$\begin{array}{c}\text { Урожайність, } \\
\text { т/га } \\
\end{array}$} & \multirow{2}{*}{$\begin{array}{c}\text { Середнє за } \\
2010-2011 \\
\text { pp. }\end{array}$} & \multirow{2}{*}{$\begin{array}{c} \pm \text { до } \\
\text { конт- } \\
\text { ролю }\end{array}$} & \multirow[t]{2}{*}{ Білок, \% } & \multirow{2}{*}{$\begin{array}{c}\text { Клейко- } \\
\text { вина }\end{array}$} \\
\hline & & & $2010 \mathrm{p}$. & $2011 \mathrm{p}$. & & & & \\
\hline 1 & \multirow{3}{*}{ Смуглянка 20.09} & 4 & 5,09 & 5,98 & 5,54 & - & 8,3 & 18,0 \\
\hline 2 & & 5 & 5,12 & 5,90 & 5,51 & - & 8,2 & 18,3 \\
\hline 3 & & 6 & 5,05 & 5,86 & 5,46 & - & 8,1 & 18,3 \\
\hline 4 & \multirow{3}{*}{$\begin{array}{c}\text { Золотоколоса } \\
20.09\end{array}$} & 4 & 5,34 & 6,18 & 5,76 & - & 8,6 & 18,3 \\
\hline 5 & & 5 & 5,40 & 6,11 & 5,76 & - & 8,1 & 18,0 \\
\hline 6 & & 6 & 5,45 & 6,04 & 5,75 & - & 8,6 & 18,5 \\
\hline 7 & \multirow{3}{*}{ Смуглянка 30.09} & 4 & 5,87 & 6,67 & 6,27 & $+0,73$ & 9,6 & 19,19 \\
\hline 8 & & 5 & 5,90 & 6,59 & 6,25 & $+0,74$ & 8,3 & 18,7 \\
\hline 9 & & 6 & 5,93 & 6,43 & 6,18 & $+0,72$ & 8,8 & 18,9 \\
\hline 10 & \multirow{3}{*}{$\begin{array}{c}\text { Золотоколоса } \\
30.09\end{array}$} & 4 & 6,03 & 6,71 & 6,37 & $+0,61$ & 8,7 & 18,7 \\
\hline 11 & & 5 & 6,21 & 6,74 & 6,48 & $+0,72$ & 8,6 & 18,5 \\
\hline 12 & & 6 & 6,07 & 6,79 & 6,44 & $+0,69$ & 9,3 & 19,7 \\
\hline 13 & \multirow{3}{*}{ Смуглянка 10.10} & 4 & 6,00 & 6,52 & 6,26 & $+0,72$ & 11,3 & 22,0 \\
\hline 14 & & 5 & 6,04 & 6,59 & 6,32 & $+0,81$ & 11,2 & 21,9 \\
\hline 15 & & 6 & 6,10 & 6,51 & 6,31 & $+0,85$ & 10,7 & 21,7 \\
\hline 16 & \multirow{3}{*}{$\begin{array}{c}\text { Золотоколоса } \\
10.10\end{array}$} & 4 & 5,87 & 6,48 & 6,18 & $+0,42$ & 10,8 & 21,2 \\
\hline 17 & & 5 & 5,90 & 6,51 & 6,21 & $+0,45$ & 11,0 & 22,0 \\
\hline 18 & & 6 & 5,93 & 6,60 & 6,27 & $+0,52$ & 11,3 & 22,3 \\
\hline 19 & \multirow{3}{*}{ Смуглянка 20.10} & 4 & 5,30 & 6,32 & 5,81 & $+0,27$ & 11,6 & 22,3 \\
\hline 20 & & 5 & 5,37 & 6,40 & 5,89 & $+0,38$ & 11,3 & 22,1 \\
\hline 21 & & 6 & 5,48 & 6,48 & 5,98 & $+0,52$ & 11,5 & 22,0 \\
\hline 22 & \multirow{3}{*}{$\begin{array}{c}\text { Золотоколоса } \\
20.10\end{array}$} & 4 & 5,49 & 6,33 & 5,91 & $+0,15$ & 10,4 & 21,1 \\
\hline 23 & & 5 & 5,63 & 6,28 & 5,96 & $+0,2$ & 10,2 & 21,0 \\
\hline 24 & & 6 & 5,65 & 6,30 & 5,98 & 5,23 & 10,9 & 21,5 \\
\hline
\end{tabular}


Строки сівби мають певний вплив на формування якості зерна, що простежується у розрізі років і зумовлено різними погодними умовами в певні фази росту рослин. Відмічена певна тенденція до зниження показників якості за ранніх строків сівби. Це обумовлюється тим, що за ранніх строків сівби чимало головних пагонів гине і величина урожайності формується переважно за рахунок пагонів кущіння, показники якості зерна 3 яких дещо нижчі. За пізніх строків сівби зазвичай спостерігається більша забур'яненість посівів, яка погіршує умови живлення та світлового режиму під час наливу й достигання зерна.

Результати наших досліджень показали, що найвищий вміст білка в зерні пшениці озимої отримано на варіанті зі строком сівби 20.10 у сорту Смуглянка - він варіював від 11,3 (5 млн схожих насінин на га) до 11,6 \% (4 млн схожих

\section{БІБЛІОГРАФІЯ}

1. Бомба М. Ф. Строки сівби та глибина загортання насіння озимої пшениці при енергозберігаючій технології / М. Ф. Бомба, В. В. Лихочвор // Вісник державного університету «Львівська політехніка» : Проблеми економії енергії. Львів : ДУ «Львівська політехніка». - 1998. C. $108-110$.

2. Когут П. М. Строки сівби та удобрення сортів озимої пшениці при інтенсивній технології вирощування / П. М. Когут, В. В. Лихочвор, В. М. Петрунів // Передгірне та гірське землеробство і тваринництво. - Вип. 35. - К. : Урожай, 1990. - С. 45-49.

3. Кононюк Л. М. Вплив строків сівби озимої пшениці на розвиток шкідливих організмів в насінин на га). У сорту Золотоколоса відзначився строк сівби 10.10 - спостерігалося збільшення вмісту білка в міру збільшення норм висіву від 10,8 до 11,3 \% (за показників на контрольному варіанті (20.09) - 8,1-8,6 \%). Аналогічна тенденція в обох досліджуваних сортів простежувалась і за визначення вмісту клейковини.

Висновки. Результати наших досліджень показали, що посіви пшениці озимої на дерновопідзолистих грунтах в умовах західного Полісся України на фоні $\mathrm{N}_{60} \mathrm{P}_{60} \mathrm{~K}_{60}$ максимальну врожайність формували за сівби сорту Золотоколоса 30.09 за норми висіву 5 млн схожих насінин на гектар (6,48 т/га), а сорт Смуглянка - за сівби 10.10 за аналогічної норми висіву $(6,32$ т/га). Найвищі якісні показники зерна пшениці (вміст білка та клейковини) отримано за сівби сорту Золотоколоса - 10.10, а Смуглянка - 20.10.

осінній період i формування врожаю зерна / Л. М. Кононюк, Л. І. Торонкова, П. В. Романюк // Землеробство. - 1992. - Вип. 67. - С. 92-95.

4. Лихочвор B. В. Роль кущіння пшениці озимої у підвищенні продуктивності рослин / В. В. Лихочвор // Вісник аграрної науки. - 2001. - № 7. C. 20-22.

5. Лихочвор В. В. Сорт і технологія / В. В. Лихочвор // Земля і люди України. -1997. - № 2. C. 16-17.

6. Носатовский А. И. Пшеница. Биология. - 2-е изд., доп. - М. : Колос, $1965 .-568$ с.

7. Федоров Н. И. Продуктивность пшеницы. Саратов : Приволж. книж. изд-во, 1980. - 176 с. 